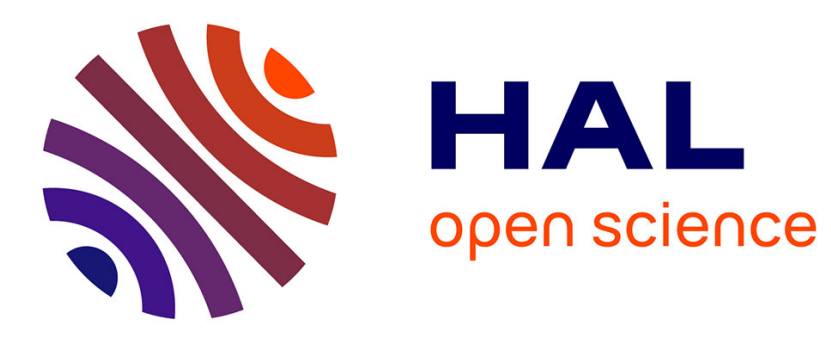

\title{
POxAP Precatalysts and the Negishi Cross-Coupling Reaction
}

Shuang-Qi Tang, Martine Schmitt, Frédéric Bihel

\section{To cite this version:}

Shuang-Qi Tang, Martine Schmitt, Frédéric Bihel. POxAP Precatalysts and the Negishi CrossCoupling Reaction. Synthesis: Journal of Synthetic Organic Chemistry, 2019, 52 (01), pp.51-59. 10.1055/s-0039-1690728 . hal-02997250

\section{HAL Id: hal-02997250 \\ https://hal.science/hal-02997250}

Submitted on 19 Nov 2020

HAL is a multi-disciplinary open access archive for the deposit and dissemination of scientific research documents, whether they are published or not. The documents may come from teaching and research institutions in France or abroad, or from public or private research centers.
L'archive ouverte pluridisciplinaire HAL, est destinée au dépôt et à la diffusion de documents scientifiques de niveau recherche, publiés ou non, émanant des établissements d'enseignement et de recherche français ou étrangers, des laboratoires publics ou privés.

\section{(ㅇ)(1) $\$$}

Distributed under a Creative Commons Attribution - NonCommercial - NoDerivatives $\mid 4.0$ 


\section{POxAP Precatalysts and the Negishi Cross-Coupling Reaction}

\section{Shuang-Qi Tang \\ Martine Schmitt \\ Frédéric Bihel*}

Laboratoire d'Innovation Thérapeutique, Faculté de Pharmacie, UMR7200, Labex Médalis, CNRS, Université de Strasbourg, 74 Route du Rhin, 67412 Illkirch, France

fbihel@unistra.fr

Click here to insert a dedication

$$
\begin{aligned}
& \mathrm{R}^{1}-\mathrm{X}^{1}+\mathrm{R}^{2}-\mathrm{Zn}-\mathrm{X}^{2} \underset{\mathrm{POxAPs}(0.1-0.001 \mathrm{~mol} \%)}{\mathrm{THF}, \mathrm{rt} \sim 80^{\circ} \mathrm{C}}-\mathrm{R}^{1}-\mathrm{R}^{2} \\
& \begin{array}{cl}
\mathrm{P}\left(\mathrm{PPh}_{3}\right)_{3} & \mathrm{Ar}=\mathrm{Ph} \text { or } 4-\mathrm{MeOC}_{6} \mathrm{H}_{4} \\
\mathrm{Ar}-\mathrm{Pd}-\mathrm{X} & \mathrm{X}=\mathrm{Cl} \text { or } \mathrm{Br} \\
\mathrm{P}\left(\mathrm{Ph}_{3}\right)_{3} & \text { TON up to } 93,000 \\
\mathrm{POxAPs} & \text { TOF up to } 2.78 \mathrm{~s}^{-1}
\end{array} \\
& \mathrm{X}^{1}=\mathrm{Cl}, \mathrm{Br}, \mathrm{I} \text { or OTf } \\
& \mathrm{X}^{2}=\mathrm{Cl} \text { or } \mathrm{Br} \\
& 29 \text { examples } \\
& 57 \% \text { to } 99 \%
\end{aligned}
$$

Abstract Recently developed for Fukuyama reaction, POxAP precatalysts are also very efficient to catalyze Negishi cross-coupling reaction between organohalides and organozinc reagents. Using very low catalyst loading, POXAPs shows similar catalytic activities than classical precatalysts such as XPhos Pd G4 or PEPPSI-IPr, with TON about 90,000. Easily prepared and stable to air and moisture, POxAPs tolerate a wide range of functional groups in the Negishi CCR, and complete advantageously the arsenal of organic chemists in terms of Pd precatalysts.

Key words Negishi cross-coupling reaction, organohalide, organozinc, palladium, precatalyst, POxAP

Palladium-catalyzed cross-coupling reactions (CCR) have been widely recognized as a highly efficient and predictable tool for the construction of carbon-carbon (C-C) bond, enabling synthetic chemists to increase the complexity and diversity of their target molecules. ${ }^{1}$ A major advance in CCR over the past two decades is likely the development of well-defined, bench-stable palladium precatalysts that do not require the addition of free ancillary ligands. $^{2}$ Indeed, specific ligands are often as expensive as palladium itself, and the traditional formation of the active $\mathrm{Pd}(0)$ by addition of excess ligand becomes particularly unattractive. By using well-defined and bench stable Pd(II) precatalyst, catalytic complex already contain one molar equivalent of ancillary ligand and can be easily and quickly transformed in active $\operatorname{Pd}(0)$ species, enabling reactions under milder conditions and with lower catalyst loadings. Although very efficient $\mathrm{Pd}(\mathrm{II})$ precatalysts have been already described in the literature, the development of alternative precatalysts could complete the tool box for CCR.

We have recently reported a novel family of precatalysts named POxAP (Post-Oxidative Addition Precatalyst) of generic formula $\operatorname{PdX}(\mathrm{Ar})\left(\mathrm{PPh}_{3}\right)_{2} \quad$ (Scheme 1$)^{3} \quad$ These palladium complexes are well-known in the literature, as they result from the first oxidative addition between a Pd(0) species and ArX in all Pd-catalyzed CCR involving aryl halides. However, they have been scarcely described per se as catalysts, with only three papers published in the 70s. ${ }^{4,5}$ Fauvarque and Jutand reported a unique example in which the complex $\mathrm{PdI}(\mathrm{Ph})\left(\mathrm{PPh}_{3}\right)_{2} / \mathrm{PPh}_{3} \quad(10$ mol\%/20 mol\%) was tested to couple $\mathrm{BrZnCH}_{2} \mathrm{CO}_{2} \mathrm{Et}$ to $\mathrm{PhI}$ in a modest $54 \%$ yield. ${ }^{5}$ Whereas iodinated POxAP (POxAP-3, Scheme 1) are moisture sensitive, brominated POxAP-1 or chlorinated POxAP-2, - 4 \& -5 appeared stable to air or moisture. In our hands, we have shown that all these POxAP precatalysts allowed the Fukuyama CCR between thioesters and organozinc reagents to be performed at room temperature with a $0.001 \%$ Pd loading and a turnover number (TON) of about $90,000 .^{3}$ We propose to describe in this article that POxAP precatalysts may also be useful for Negishi CCR between organozinc reagents and aryl halides.

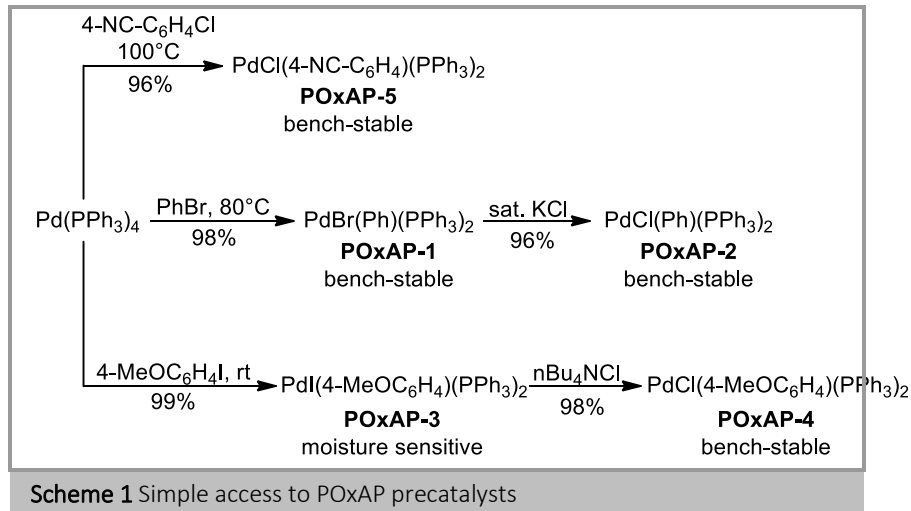

Starting from $\mathrm{Pd}\left(\mathrm{PPh}_{3}\right)_{4}$, we were able to synthesize several POxAP precatalysts in gram scale in almost quantitative yields (Scheme 1). The temperature of the oxidative addition was directly linked to the nature of the halide $(\mathrm{Cl}>\mathrm{Br}>>\mathrm{I})$. Geometry of these precatalysts are well defined as shown by the X-ray structure of POxAP-2 (Figure 1) which was fully consistent with the one published by Flemming. ${ }^{6}$ 


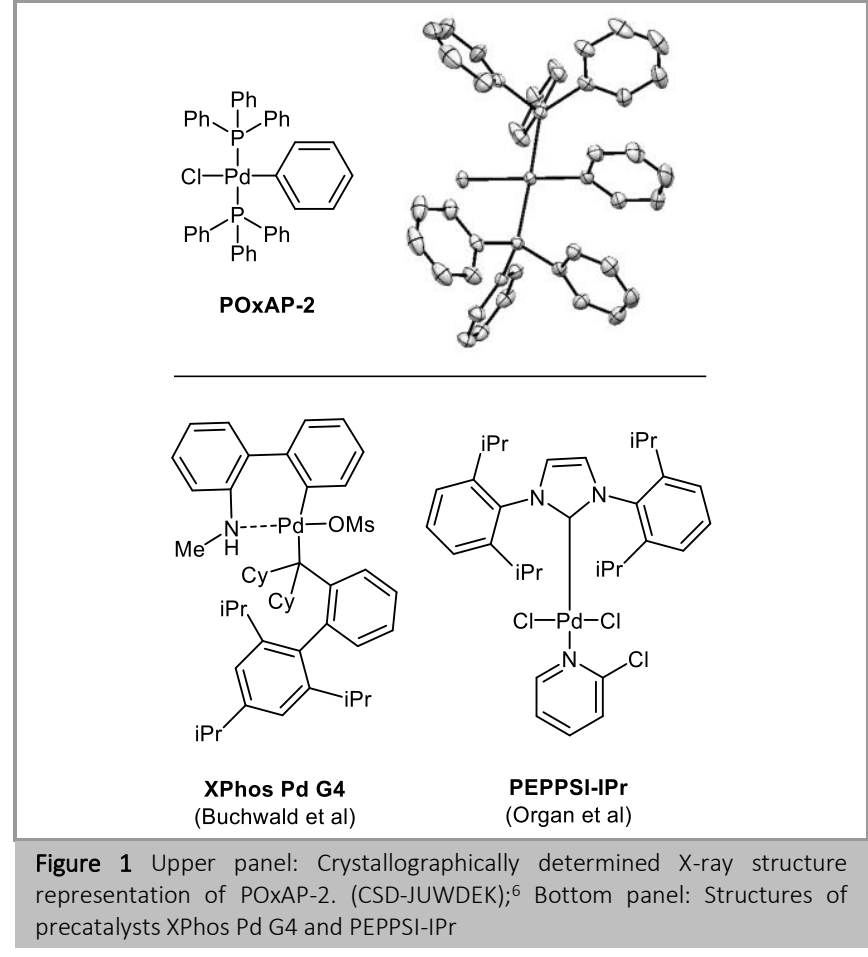

As a starting point, we used standard Negishi CCR conditions to couple 4- $\mathrm{MeOC}_{6} \mathrm{H}_{4} \mathrm{I}$ with $\mathrm{BnZnBr}$ in THF at $80{ }^{\circ} \mathrm{C}$, but with a very low Pd loading (0.001 mol\%) (Table 1 and Figure $2 \mathrm{~A}$ ). Under these conditions, $\mathrm{PdCl}_{2}\left(\mathrm{PPh}_{3}\right)_{2}$ appeared poorly efficient, affording the coupling product $2 \mathbf{a}$ in $14 \%$ yield. In comparison, both POxAP-4 \& -1 led to yields ranging from $89 \%$ to $93 \%$, respectively. Both POxAPs were compared to XPhos Pd G4 and PEPPSI-IPr, two classical precatalysts for Negishi CCR (Figure 1). XPhos Pd G4 belongs to the $4^{\text {th }}$ generation of palladacycle precatalysts developed by Buchwald et al., ${ }^{7}$ while PEPPSI-IPr is an organopalladium complex containing an $\mathrm{N}$-heterocyclic carbene (NHC) ligand developed by Organ et al. ${ }^{8}$ Both precatalysts are easy to prepare, stable under air or moisture, and are commonly used in various CCRs including Negishi CCR. ${ }^{2}$ While these two classical precatalysts were found less efficient in the Fukuyama CCR, ${ }^{3}$ they were found as expected very potent to catalyze the Negishi CCR shown in Table 1, affording compound 2a in about $90 \%$ yield and TON of about 90,000 . We were pleased to observe very similar values for POxAP-1 \& -4 . XPhos Pd G4 appeared to be the "fastest" precatalyst with an initial turnover frequency (TOF) of $3.89 \mathrm{~s}^{-1}$, while POxAP-4 was significantly slower $\left(1.11 \mathrm{~s}^{-1}\right)$ (Table 1 and Figure 2B). However, it is important to notice that these TOFs, measured during the first 30 minutes, highlight somehow the kinetic of formation of the catalytically-active $\mathrm{Pd}(0)$ species. Indeed, TOFs measured between $1 \mathrm{~h}$ and $3 \mathrm{~h}$ showed similar "cruising" rates, ranging from 1.4 to $1.8 \mathrm{~s}^{-1}$, for the four precatalysts (Table 1 and Figure 2C).
Table 1 Kinetic study of precatalyst-catalyzed Negishi CCR

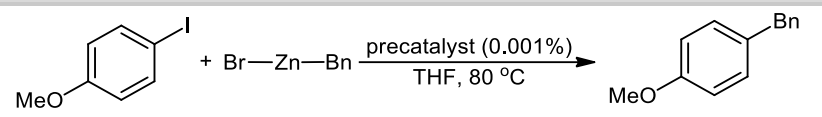

1a

\begin{tabular}{|c|c|c|c|c|c|}
\hline \multirow[b]{2}{*}{ Entry } & \multirow[b]{2}{*}{$\begin{array}{l}\text { Catalyst } \\
(0.001 \mathrm{~mol} \%)\end{array}$} & \multirow[b]{2}{*}{ TON } & \multicolumn{2}{|c|}{$\operatorname{TOF}\left(\mathrm{s}^{-1}\right)$} & \multirow[b]{2}{*}{$\begin{array}{l}\text { Yield } \\
(\%)^{\mathrm{e}}\end{array}$} \\
\hline & & & $\begin{array}{l}\text { Initial } \\
\text { rate }^{c}\end{array}$ & $\begin{array}{l}\text { Cruising } \\
\text { rate }^{\mathrm{d}}\end{array}$ & \\
\hline 1 & $\mathrm{PdCl}_{2}\left(\mathrm{PPh}_{3}\right)_{2}$ & 14,000 & 0.56 & 0.28 & 14 \\
\hline 2 & POXAP-4 & 89,000 & 1.11 & 1.67 & 89 \\
\hline 3 & POXAP-1 & 93,000 & 2.78 & 1.67 & 93 \\
\hline 4 & XPhos Pd G4 & 92,000 & 3.89 & 1.81 & 92 \\
\hline 5 & PEPPSI iPr & 87,000 & 2.22 & 1.39 & 87 \\
\hline
\end{tabular}

${ }^{a}$ Reaction conditions: 1 -iodo-4-methoxybenzene $(0.2 \mathrm{mmol}), 1 \mathrm{a}(0.3 \mathrm{mmol}, 0.37$ $\mathrm{mL}, 0.82 \mathrm{M}$ in THF), precatalyst $\left(0.001 \mathrm{~mol} \%, 0.1 \mathrm{~mL}, 2 \times 10^{-5} \mathrm{M}\right.$ in THF), $80^{\circ} \mathrm{C}$. ${ }^{b}$ TON was calculated by the yield at $40 \mathrm{~h}$.

${ }^{c}$ Initial rate was measured between 0 and $30 \mathrm{~min}$.

${ }^{\mathrm{d}}$ Cruising rate was measured between 1 and $3 \mathrm{~h}$.

e Yield of 2a was determined from the average of two independent experiments after $40 \mathrm{~h}$ by HPLC/UV using caffeine as an internal standard.
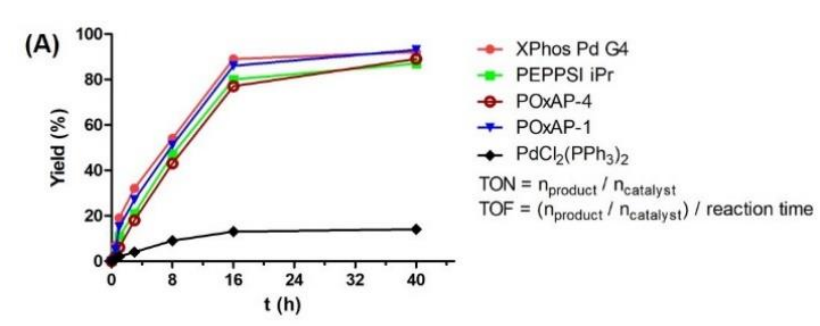

(B)

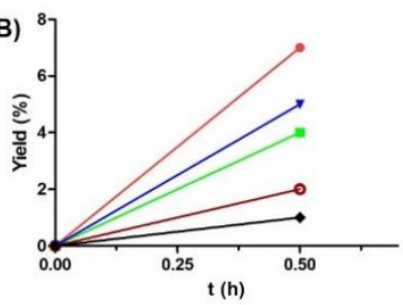

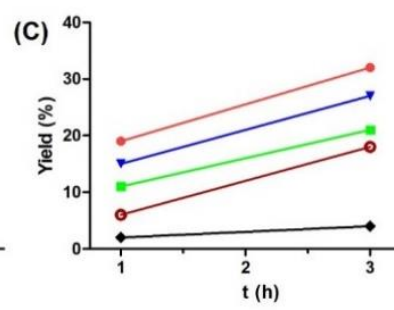

Figure 2 (A) Kinetic curves $(0-40 \mathrm{~h})$ of precatalyst-catalyzed Negishi CCR in Table 1; (B) Initial rate curves (0-30 min); (C) Cruising rate curves (1-3 h)

After establishing the potency of POxAPs to catalyze Negishi CCR in a model reaction, we established the scope of POxAP-1 to cross-couple various aryl halides (Scheme 2) as well as various organozinc reagents (Scheme 3 ).

First, a diverse set of (hetero)aryl halides was investigated in presence of benzylzinc bromide (1a) with 0.1 mol\% precatalyst loading (Scheme 2). Optimal reaction time and temperature were determined for each substrate in order to characterize the influence of substituents on reaction. As a standard, 1-benzyl-4methoxybenzene (2a) was obtained in $98 \%$ yield $\left(80{ }^{\circ} \mathrm{C}, 6 \mathrm{~h}\right)$ from the coupling reaction of 1-bromo-4-methoxybenzene with 1a. Replacement of bromine by iodine or triflate facilitated the reaction, giving $\mathbf{2 a}$ in nearly quantitative yield at lower temperature $\left(50^{\circ} \mathrm{C}\right)$ after 6 or $3 \mathrm{~h}$, respectively. In contrast, 4methoxy-chlorobenzene was less reactive and even at $120^{\circ} \mathrm{C}$, no reaction was observed. Interestingly, after replacing the electrondonating methoxy group by an electron-accepting cyano group, the corresponding aryl chloride became reactive enough to afford the expected product $\mathbf{2 b}$ in $99 \%$ yield, after $6 \mathrm{~h}$ at $80^{\circ} \mathrm{C}$. Overall, aryl halides bearing electron-withdrawing substituents were generally coupled at lower temperatures $\left(50^{\circ} \mathrm{C}\right)$ than those bearing electron-donating groups $\left(80^{\circ} \mathrm{C}\right)$. This is perfectly 
consistent with structure-activity relationships in Negishi CCR reported by Mayr et al., in which they showed that this CCR is accelerated by the presence of electron-acceptor on aryl halides. ${ }^{9}$ As expected, precatalyst POxAP-1 did not alter the high tolerance of the Negishi CCR for a large variety of functional groups, including cyanide (2b), amide (2c), ketone (2d), aldehyde $(\mathbf{2 j})$ and free amine $(\mathbf{2 k})$. Even the reaction with the bulky $o, o^{\prime}$ dimethylbromobenzene efficiently provided the target compound (2l) in nearly quantitative yield. Taken into account the difference of reactivity between halides ( $>\mathrm{Br}>>\mathrm{Cl}>>\mathrm{F}$ ), chemoselective couplings were obtained in quantitative yields when starting from aryl bearing 2 different halides (2e-g) Heteroaryl halides, including N, O or S heteroatoms, appeared very reactive and led to coupling products at temperatures below $50{ }^{\circ} \mathrm{C}(\mathbf{2 m}-\mathbf{q})$. Finally, we tested the capability to couple an alkyl group (3-phenyl-benzylbromide) with $0.1 \mathrm{~mol} \% \mathrm{Pd}$ loading, and product $2 \mathbf{r}$ was recovered in quantitative yield after only $1 \mathrm{~h}$ at $80^{\circ} \mathrm{C}$.

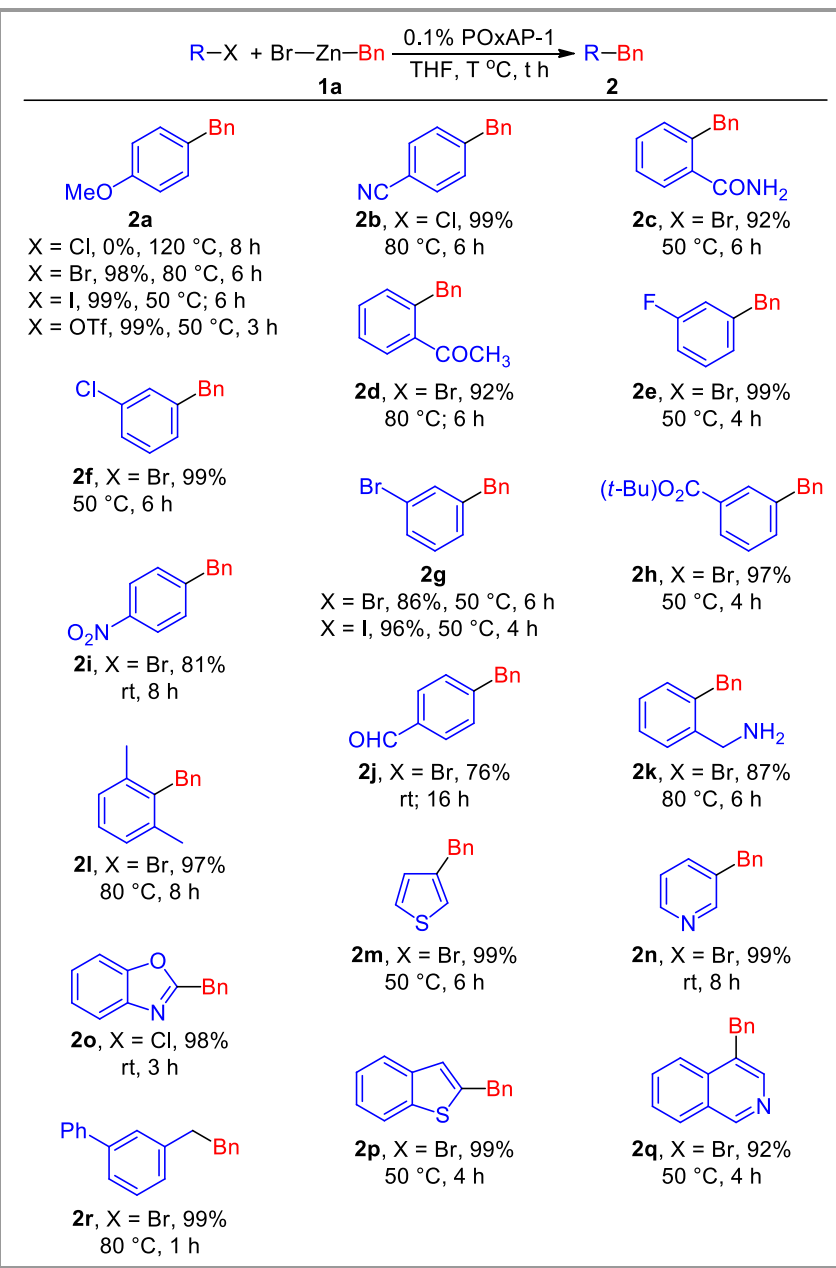

Scheme $2 \mathrm{PdBr}(\mathrm{Ph})\left(\mathrm{PPh}_{3}\right)_{2}$-catalyzed Negishi CCR of halide and benzylzinc bromide (1a). Reaction conditions: halide (1 mmol), POxAP-1 $(0.1 \mathrm{~mol} \%, 1 \mathrm{~mL}$, $10^{-3} \mathrm{M}$ in THF), $1 \mathrm{a}$ (1.5 mmol, $1.9 \mathrm{~mL}, 0.8 \mathrm{M}$ in THF).

Next, we turned our attention to probe the scope of a diverse set of organozinc reagents (Scheme 3). 3-bromopyridine was used as model substrate and coupled at room temperature in presence of POxAP-1 (0.1 mol\%). Phenylzinc chloride or 3pyridylzinc chloride led to corresponding biaryls in excellent yields (3a-b), as well as alkylzinc halides (3c-i) or alkenylzinc chloride (3j). Ethynylzinc chloride reagent led to compound $\mathbf{3 k}$ in a modest $57 \%$ yield, due to the formation of the side product 1,2-di(pyridin-3-yl)ethyne (11\% yield) resulting from the double coupling reaction on the triple bond. ${ }^{10}$ Again, POxAP-catalyzed Negishi CCR is very tolerant, allowing the presence of functional groups such as cyanide (3d, 91\%), sylilated alcohol (3e, 91\%), phthalimide (3f, 83\%), or alkylated phosphonate (3g, 74\%). Starting from organozinc bromomethyl-phenylboronic propane1,3-diol ester, the reaction afforded after purification the free boronic acid derivative (3h) in good yield (71\%). With ester group, the coupling product $3 \mathbf{i}$ was obtained in $63 \%$ yield, and the product of homocoupling 3,3'-bipyridine was isolated in $14 \%$ yield. ${ }^{11}$

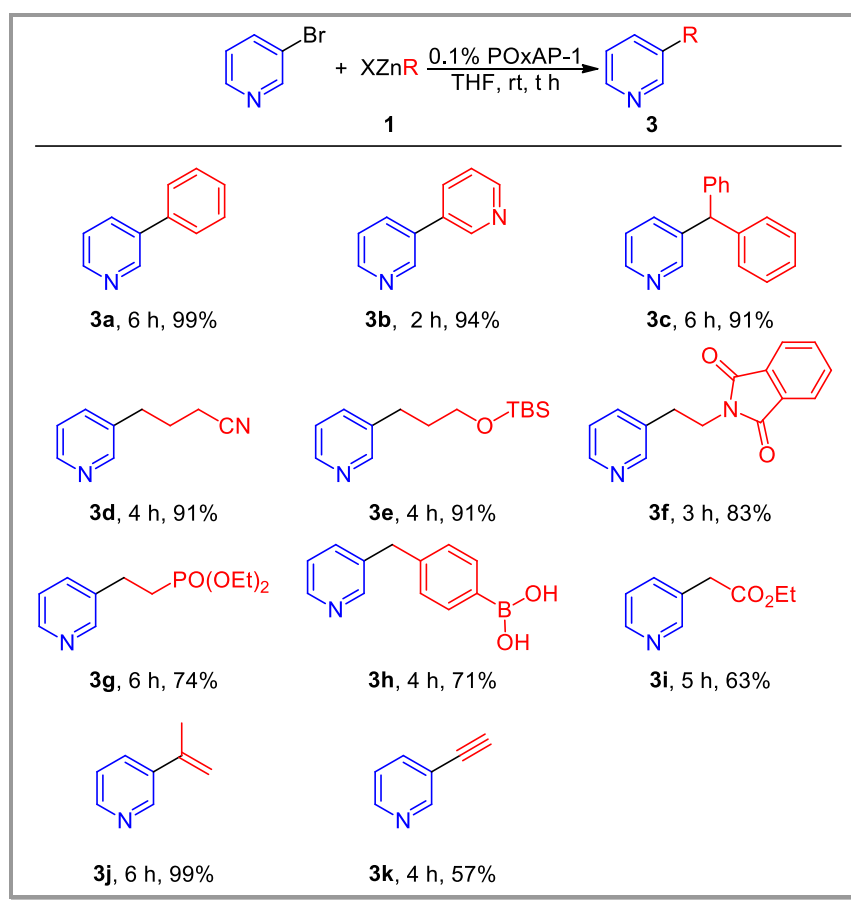

Scheme $3 \mathrm{PdBr}(\mathrm{Ph})\left(\mathrm{PPh}_{3}\right)_{2}$-catalyzed Negishi $\mathrm{CCR}$ of 3-bromopyridine and organozinc reagents (1). Reaction conditions: 3-bromopyridine (1 mmol), POXAP-1 (0.1 mol \%, $1 \mathrm{~mL}, 10^{-3} \mathrm{M}$ in THF), 1 (1.5 mmol in THF), rt.

POxAPs result from the first oxidative addition between a $\operatorname{Pd}(0)$ species and $\operatorname{ArX}$, and so they respect the criteria of Pdbased OACs (Oxidative Addition Complexes) recently described by Ingoglia and Buchwald. ${ }^{12}$ Consequently, we proposed a catalytic cycle for the current POxAP-catalyzed Negishi CCR in Scheme 4 . In the presence of organozinc reagent $\mathrm{R}^{1} \mathrm{ZnX}, \mathrm{POXAP}$ follows an initiation step and provides $\mathrm{PhR}^{1}$ as well as a reactive $\operatorname{Pd}(0)$ entity, which is then available for a subsequent Negishi catalytic cycle. A proof of the proposed mechanism was determined in the Fukuyama CCR, ${ }^{3}$ where we were able to detect 3-phenylpyridine $\left(\mathrm{Ph}-\mathrm{R}^{1}\right)$ by mass spectroscopy, whose formation could be explained by an initiation step between POxAP-1 and pyridin-3-ylzinc bromide followed by a reductive elimination. This mechanism is also consistent with the fact that POxAP-1 and -4 showed differences in initial rates (Table $1, t<$ $30 \mathrm{~min}, \mathrm{TOF}=2.8 \mathrm{vs} \& 1.1 \mathrm{~s}^{-1}$, respectively, but exhibit identical "cruising" rate (Table $1,1 \mathrm{~h}<\mathrm{t}<3 \mathrm{~h}$, TOF $=1.67 \& 1.67 \mathrm{~s}^{-1}$, respectively), as both POxAPs lead to the same reactive $\operatorname{Pd}(0)$ entity after the initiation step. 


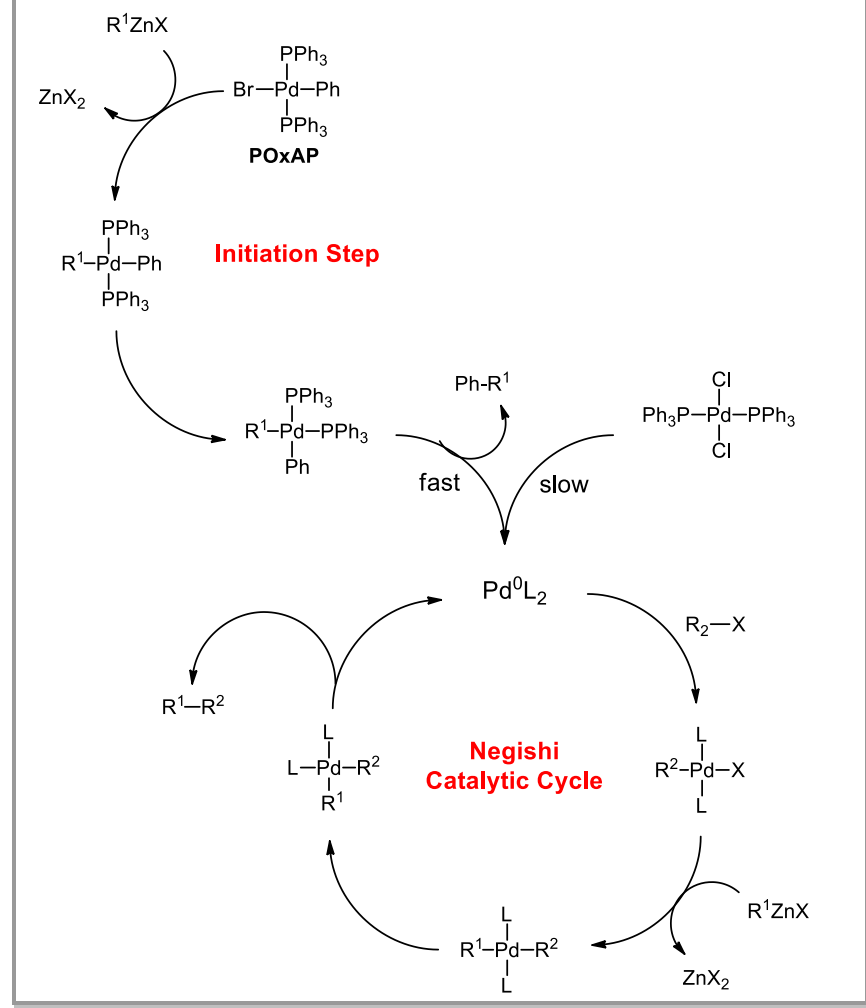

Scheme 4 Mechanism of POxAP-catalyzed Negishi CCR

In summary, we have demonstrated that POxAP precatalysts are very efficient in Negishi CCR, with comparable activities to classical precatalysts XPhos Pd G4 or PEPPSI-IPr. With $0.1 \%$ POxAP-1 $\left(\mathrm{PdBr}(\mathrm{Ph})\left(\mathrm{PPh}_{3}\right)_{2}\right), 1 \mathrm{mmol}$ aryl halide could be coupled with diverse organozinc reagents within 1 to $16 \mathrm{~h}$, furnishing the corresponding products in high yields. Moreover, POxAP-1catalyzed Negishi CCR has a good chemoselectivity (OTf $\approx \mathrm{I}>\mathrm{Br}$ $>\mathrm{Cl}>>\mathrm{F}$ ), as well as an extensive functional groups tolerance, such as nitro, amino, amide, ketone, aldehyde, alkene, alkyne, cyano, carboxylate, TBS-alcohol, phthalimide, phosphonate and borate. Easily prepared and stable to air and moisture, POxAPs complete the toolbox of organic chemists in terms of precatalysts exhibiting very high catalytic activities in the formation of $\mathrm{C}-\mathrm{C}$ bond starting from organozinc reagents. These POxAPs will be next evaluated for their capabilities to catalyze other CCRs.

\section{The experimental section has no title; please leave this line here.}

All commercial reagents were used without additional purification. POxAPs were prepared according to the previous reported methods. ${ }^{3}$ All the glassware were properly dried in an oven before use. ${ }^{1} \mathrm{H}(400$ or 500 $\mathrm{MHz}$ ) and ${ }^{13} \mathrm{C}$ (101 or $126 \mathrm{MHz}$ ) NMR spectra were recorded on Bruker Avance Spectrometer and internally referenced to the residual solvent signals ( ${ }^{1} \mathrm{H} \mathrm{NMR}: \mathrm{CDCl}_{3}, \delta=7.26$; ${ }^{13} \mathrm{C} \mathrm{NMR}: \mathrm{CDCl}_{3}, \delta=77.16$ ). All chemical shift values $\delta$ and coupling constants $J$ are quoted in ppm and in $\mathrm{Hz}$, respectively. HPLC were performed using a Dionex UltiMate 3000 using the following parameters: Flow rate of $0.5 \mathrm{~mL} / \mathrm{min}$, column temperature: $30{ }^{\circ} \mathrm{C}$, solvent system: $\mathrm{A}(\mathrm{MeOH})$ and $\mathrm{B}(0.05 \%$ of TFA in $\mathrm{H} 2 \mathrm{O}), \mathrm{t}=0 \mathrm{~min}$ to $1 \mathrm{~min}$ : 50 to $60 \%$ of $\mathrm{B}$, then $\mathrm{t}=1 \mathrm{~min}$ to $\mathrm{t}=10 \mathrm{~min}: 60$ to $100 \%$ of $\mathrm{B}$ and $\mathrm{t}=10 \mathrm{~min}$ to $\mathrm{t}=15 \mathrm{~min}: 100 \%$ of $\mathrm{B}$.

\section{Preparation of organozinc reagents}

\section{Typical procedure 1 (TP1)}

Organozinc reagents were prepared as described by Knochel et al. ${ }^{13}$ An oven-dried $20 \mathrm{~mL}$ microwave vial equipped with a magnetic stirrer was charged with zinc (1.5 equiv, $491 \mathrm{mg}, 7.5 \mathrm{mmol}$ ) and LiCl (1.5 equiv, 318 $\mathrm{mg}, 154 \mu \mathrm{L}, 7.5 \mathrm{mmol}$ ). The vial was properly capped and heated using a heat gun $\left(350{ }^{\circ} \mathrm{C}, 10 \mathrm{~min}\right)$ under reduced pressure, then cooled to $\mathrm{rt}$, degassed and backfilled with argon thrice. THF (5.2 mL for liqiud halides and $4.2 \mathrm{~mL}$ for solid halides) was added followed by 1,2-dibromoethane (5 \%, $21.6 \mu \mathrm{L}, 0.25 \mathrm{mmol}$ ) and chlorotrimethylsilane (5\%, $32 \mu \mathrm{L}, 0.25$ mmol). The suspension was heated $\left(50{ }^{\circ} \mathrm{C}, 2 \mathrm{~min}\right)$ until the suspension became clear and grey precipitates formed. After cooling to $\mathrm{rt}$, the corresponding halide ( 1 equiv, $5 \mathrm{mmol}$ ) was added dropwise at $-10{ }^{\circ} \mathrm{C}$ (solid halides were dissolved in $1 \mathrm{~mL}$ THF before adding). The resulted solution was stirred at $0{ }^{\circ} \mathrm{C}$ for $30 \mathrm{~min}$, then at the given temperature for the given time to afford corresponding organozinc reagent. The concentration and yield of the organozinc reagent were determined by iodometric titration of the supernatant solution according to the following formulas ${ }^{14}$

$\mathrm{C}=\mathrm{m} / 254 / \mathrm{V}_{\text {organozinc }}$

Yield $=\left(\mathrm{C} \times \mathrm{V}_{\text {total }}\right) / 5$

$\mathrm{m}$ : weight of iodine $(\mathrm{mg})$

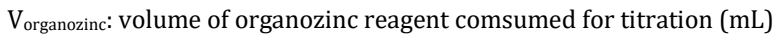

$\mathrm{V}_{\text {total }}$ : total volume of organozinc reagent $(\mathrm{mL})$

\section{Typical procedure 2 (TP2)}

Organozinc reagents were prepared as described by Knochel et al. ${ }^{15}$ An oven-dried $20 \mathrm{~mL}$ microwave vial equipped with a magnetic stirrer was charged with $\mathrm{ZnCl}_{2}$ (1.5 equiv, $1.02 \mathrm{~g}, 7.5 \mathrm{mmol}$ ) and $\mathrm{LiCl}$ (1.5 equiv, 318 $\mathrm{mg}, 154 \mu \mathrm{L}, 7.5 \mathrm{mmol}$ ). The vial was properly capped and heated using a heat gun $\left(550{ }^{\circ} \mathrm{C}, 15 \mathrm{~min}\right)$ under reduced pressure, then cooled to $\mathrm{rt}$, degassed and backfilled with argon thrice. THF ( $5 \mathrm{~mL}$ for $1 \mathrm{M}$ and $7.5 \mathrm{~mL}$ for $2 \mathrm{M}$ Grignard reagents) was added and the mixture was ultrasonicated until it became a clear solution (skip this step if the concentration of Grignard reagent is $0.5 \mathrm{M}$ ). The corresponding organomagnesium bromide (1 equiv, $5 \mathrm{mmol}$ ) was slowly added to aforementioned solution at $0{ }^{\circ} \mathrm{C}$ (final volumn $=10 \mathrm{~mL}$ ) and a white precipitate was observed. The resulting mixture was stirred at $\mathrm{rt}$ for additional $3 \mathrm{~h}$ to afford the corresponding organozinc reagent $(0.5 \mathrm{M})$, which was used directly without titration.

\section{benzylzinc(II) bromide (1a)}

1a was prepared from $0.6 \mathrm{~mL}$ (bromomethyl)benzene at rt in $16 \mathrm{~h}$ according to typical procedure TP1 (96\%, $0.8 \mathrm{M})$.

\section{phenylzinc(II) chloride (1b)}

1b was prepared from $5 \mathrm{~mL}$ phenylmagnesium bromide (1 $\mathrm{M}$ in THF) at $\mathrm{rt}$ in $3 \mathrm{~h}$ according to typical procedure TP2 (100\%, $0.5 \mathrm{M})$.

\section{pyridin-3-ylzinc(II) chloride (1c)}

1c was prepared from $0.48 \mathrm{~mL} 3$-bromopyridine according to a previous reported method $(64 \%, 0.3 \mathrm{M}) .^{3}$

\section{benzhydrylzinc(II) bromide (1d)}

1d was prepared from $1.23 \mathrm{~g}$ (bromomethylene)dibenzene at -10 in $3 \mathrm{~h}$ according to typical procedure TP1 (70\%, $0.55 \mathrm{M})$.

\section{(3-cyanopropyl)zinc(II) bromide (1e)}

1e was prepared from $0.5 \mathrm{~mL}$ 4-bromobutanenitrile at $80{ }^{\circ} \mathrm{C}$ in $16 \mathrm{~h}$ according to typical procedure TP1 (74\%, $0.62 \mathrm{M})$.

(3-((tert-butyldimethylsilyl)oxy)propyl)zinc(II) bromide (1f) 
1f was prepared from $1.16 \mathrm{~mL}$ (3-bromopropoxy)(tertbutyl)dimethylsilane at $80^{\circ} \mathrm{C}$ in $16 \mathrm{~h}$ according to typical procedure TP1 (86\%, $0.66 \mathrm{M})$.

\section{(2-(1,3-dioxoisoindolin-2-yl)ethyl)zinc(II) bromide (1g)}

$1 \mathrm{~g}$ was prepared from $1.34 \mathrm{~g}$ 2-(2-bromoethyl)isoindoline-1,3-dione at 80 ${ }^{\circ} \mathrm{C}$ in $20 \mathrm{~h}$ according to typical procedure TP1 $(81 \%, 0.58 \mathrm{M})$.

\section{(2-(diethoxyphosphoryl)ethyl)zinc(II) bromide (1h)}

$1 \mathrm{~h}$ was prepared from $1.53 \mathrm{~mL}$ diethyl (2-bromoethyl)phosphonate at 50 ${ }^{\circ} \mathrm{C}$ in $6 \mathrm{~h}$ according to typical procedure TP1 (97\%, $\left.0.69 \mathrm{M}\right)$.

\section{(4-(1,3,2-dioxaborinan-2-yl)benzyl)zinc(II) bromide (1i)}

1i was prepared from $1.27 \mathrm{~g}$ 2-(4-(bromomethyl)phenyl)-1,3,2dioxaborinane at rt in $16 \mathrm{~h}$ according to typical procedure TP1 (84\%, 0.64 M)

\section{(2-ethoxy-2-oxoethyl)zinc(II) bromide (1j)}

1j was prepared from $0.55 \mathrm{~mL}$ ethyl 2-bromoacetate at $40{ }^{\circ} \mathrm{C}$ in $5 \mathrm{~h}$ according to typical procedure TP1 $(88 \%, 0.73 \mathrm{M})$.

\section{prop-1-en-2-ylzinc(II) chloride (1k)}

$1 \mathbf{k}$ was prepared from $10 \mathrm{~mL}$ prop-1-en-2-ylmagnesium bromide $(0.5 \mathrm{M}$ in THF) at rt in $3 \mathrm{~h}$ according to typical procedure TP2 $(100 \%, 0.5 \mathrm{M})$.

\section{ethynylzinc(II) chloride (1I)}

11 was prepared from $10 \mathrm{~mL}$ ethynylmagnesium bromide $(0.5 \mathrm{M}$ in THF $)$ at rt in $3 \mathrm{~h}$ according to typical procedure TP2 (100\%, $0.5 \mathrm{M})$.

\section{General procedure of $\operatorname{PdBr}(\mathrm{Ph})\left(\mathrm{PPh}_{3}\right)_{2}$-catalyzed Negishi CCR}

An oven-dried $20 \mathrm{~mL}$ microwave vial equipped with a magnetic stirrer was charged with halide (1 equiv, $1 \mathrm{mmol})$ and $\operatorname{PdBr}(\mathrm{Ph})\left(\mathrm{PPh}_{3}\right)_{2}(0.1 \mathrm{~mol}$ $\%, 1 \mathrm{~mL}, 10^{-3} \mathrm{M}$ in THF, $1 \mathrm{~mL}$ ). The vial was properly capped and degassed/backfilled with argon thrice. Then, the solution of organozinc reagent (1.5 equiv, $1.5 \mathrm{mmol}$ ) in THF was slowly added to the mixture at rt. The reaction temperature and time were listed in Scheme 2 and 3. After completion, the reaction mixture was quenched with saturated $\mathrm{NH}_{4} \mathrm{Cl}$ solution $(10 \mathrm{~mL})$ and extracted with EtOAc $(10 \mathrm{~mL})$ thrice. The combined organic phases were concentrated in vacuo and purified by reverse phase chromatography $\left(\mathrm{MeOH} / \mathrm{H}_{2} \mathrm{O}\right)$ to afford the coupled products.

\section{1-benzyl-4-methoxybenzene (2a)}

Eluent: $\mathrm{MeOH} / \mathrm{H}_{2} \mathrm{O}$ (50:50); colorless oil; yield: $196 \mathrm{mg}$ ( $0.99 \mathrm{mmol}$, 99\%). ${ }^{1} \mathrm{H}$ NMR (400 MHz, $\left.\mathrm{CDCl}_{3}\right) \delta 7.31(\mathrm{t}, J=7.3 \mathrm{~Hz}, 2 \mathrm{H}), 7.25-7.17(\mathrm{~m}, 3 \mathrm{H})$ $7.13(\mathrm{~d}, J=8.4 \mathrm{~Hz}, 2 \mathrm{H}), 6.86(\mathrm{~d}, J=8.6 \mathrm{~Hz}, 2 \mathrm{H}), 3.96(\mathrm{~s}, 2 \mathrm{H}), 3.81(\mathrm{~s}, 3 \mathrm{H})$.

These data are consistent with the previously reported characterization. ${ }^{16}$

\section{4-benzylbenzonitrile (2b)}

Eluent: $\mathrm{MeOH} / \mathrm{H}_{2} \mathrm{O}$ (40:60); colorless oil; yield: $191 \mathrm{mg}$ ( $0.99 \mathrm{mmol}$, 99\%). ${ }^{1} \mathrm{H}$ NMR $\left(400 \mathrm{MHz}, \mathrm{CDCl}_{3}\right) \delta 7.54-7.50(\mathrm{~m}, 2 \mathrm{H}), 7.29-7.17(\mathrm{~m}, 5 \mathrm{H}), 7.13$ - $7.08(\mathrm{~m}, 2 \mathrm{H}), 3.98(\mathrm{~s}, 2 \mathrm{H})$

These data are consistent with the previously reported characterization. ${ }^{17}$

\section{2-benzylbenzamide (2c)}

Eluent: $\mathrm{MeOH} / \mathrm{H}_{2} \mathrm{O}$ (40:60); white solid; yield: $194 \mathrm{mg}(0.92 \mathrm{mmol}, 92 \%)$
${ }^{1} \mathrm{H} \mathrm{NMR}\left(400 \mathrm{MHz}, \mathrm{CDCl}_{3}\right) \delta 7.48(\mathrm{dd}, J=7.6,1.2 \mathrm{~Hz}, 1 \mathrm{H}), 7.37(\mathrm{td}, J=7.5$ $1.4 \mathrm{~Hz}, 1 \mathrm{H}), 7.30$ - $7.22(\mathrm{~m}, 4 \mathrm{H}), 7.22-7.16(\mathrm{~m}, 3 \mathrm{H}), 5.68(\mathrm{br}, 2 \mathrm{H}), 4.25$ (s, $2 \mathrm{H})$.

These data are consistent with the previously reported characterization. ${ }^{18}$

\section{1-(2-benzylphenyl)ethanone (2d)}

Eluent: $\mathrm{MeOH} / \mathrm{H}_{2} \mathrm{O}$ (40:60); colorless oil; yield: $193 \mathrm{mg}$ (0.92 mmol, 92\%). ${ }^{1} \mathrm{H}$ NMR $\left(500 \mathrm{MHz}, \mathrm{CDCl}_{3}\right) \delta 7.54(\mathrm{dd}, J=7.7,1.3 \mathrm{~Hz}, 1 \mathrm{H}), 7.30(\mathrm{td}, J=7.5$ $1.4 \mathrm{~Hz}, 1 \mathrm{H}), 7.20(\mathrm{td}, J=7.6,1.2 \mathrm{~Hz}, 1 \mathrm{H}), 7.17-7.12(\mathrm{~m}, 3 \mathrm{H}), 7.07(\mathrm{t}, J=7.4$ $\mathrm{Hz}, 1 \mathrm{H}), 7.03(\mathrm{~d}, J=7.5 \mathrm{~Hz}, 2 \mathrm{H}), 4.18(\mathrm{~s}, 2 \mathrm{H}), 2.36(\mathrm{~s}, 3 \mathrm{H})$.

These data are consistent with the previously reported characterization. ${ }^{19}$

\section{1-benzyl-3-fluorobenzene (2e)}

Eluent: $\mathrm{MeOH} / \mathrm{H}_{2} \mathrm{O}$ (60:40); colorless oil; yield: $184 \mathrm{mg}$ ( $0.99 \mathrm{mmol}$, 99\%). ${ }^{1} \mathrm{H}$ NMR $\left(400 \mathrm{MHz}, \mathrm{CDCl}_{3}\right) \delta 7.29-7.23(\mathrm{~m}, 2 \mathrm{H}), 7.22-7.17(\mathrm{~m}, 2 \mathrm{H}), 7.16$ - $7.12(\mathrm{~m}, 2 \mathrm{H}), 6.93(\mathrm{~d}, J=7.3 \mathrm{~Hz}, 1 \mathrm{H}), 6.88-6.80(\mathrm{~m}, 2 \mathrm{H}), 3.93(\mathrm{~s}, 2 \mathrm{H})$.

These data are consistent with the previously reported characterization. ${ }^{20}$

\section{1-benzyl-3-chlorobenzene (2f)}

Eluent: $\mathrm{MeOH} / \mathrm{H}_{2} \mathrm{O}$ (60:40); yellow oil; yield: $200 \mathrm{mg}$ ( $0.99 \mathrm{mmol}$, 99\%). ${ }^{1} \mathrm{H} \mathrm{NMR}\left(400 \mathrm{MHz}, \mathrm{CDCl}_{3}\right) \delta 7.23(\mathrm{t}, J=7.3 \mathrm{~Hz}, 2 \mathrm{H}), 7.17-7.09(\mathrm{~m}, 6 \mathrm{H})$, $7.00(\mathrm{~d}, J=7.1 \mathrm{~Hz}, 1 \mathrm{H}), 3.88(\mathrm{~s}, 2 \mathrm{H})$.

These data are consistent with the previously reported characterization. ${ }^{21}$

\section{1-benzyl-3-bromobenzene (2g)}

Eluent: $\mathrm{MeOH} / \mathrm{H}_{2} \mathrm{O}$ (60:40); yellow oil; yield: $237 \mathrm{mg}$ ( $0.96 \mathrm{mmol}$, 96\%).

${ }^{1} \mathrm{H} \mathrm{NMR}\left(400 \mathrm{MHz}, \mathrm{CDCl}_{3}\right) \delta 7.36-7.28(\mathrm{~m}, 4 \mathrm{H}), 7.22(\mathrm{t}, J=7.4 \mathrm{~Hz}, 1 \mathrm{H})$, $7.19-7.09(\mathrm{~m}, 4 \mathrm{H}), 3.95(\mathrm{~s}, 2 \mathrm{H})$

These data are consistent with the previously reported characterization..$^{22}$

\section{tert-butyl 3-benzylbenzoate (2h)}

Eluent: $\mathrm{MeOH} / \mathrm{H}_{2} \mathrm{O}$ (70:30); colorless oil; yield: $260 \mathrm{mg}$ ( $0.97 \mathrm{mmol}$, 97\%). ${ }^{1} \mathrm{H}$ NMR $\left(500 \mathrm{MHz}, \mathrm{CDCl}_{3}\right) \delta 7.90-7.88(\mathrm{~m}, 1 \mathrm{H}), 7.88-7.84(\mathrm{~m}, 1 \mathrm{H}), 7.37$ - $7.34(\mathrm{~m}, 2 \mathrm{H}), 7.31(\mathrm{t}, J=7.5 \mathrm{~Hz}, 2 \mathrm{H}), 7.25-7.19(\mathrm{~m}, 3 \mathrm{H}), 4.04(\mathrm{~s}, 2 \mathrm{H})$, $1.61(\mathrm{~s}, 9 \mathrm{H})$.

${ }^{13} \mathrm{C}$ NMR $\left(126 \mathrm{MHz}, \mathrm{CDCl}_{3}\right) \delta 165.94,141.33,140.70,133.14,132.31$, $130.00,129.00,128.66,128.45,127.38,126.35,81.05,41.85,28.31$. GC-MS: $\mathrm{m} / \mathrm{z}=268.146$.

\section{1-benzyl-4-nitrobenzene (2i)}

Eluent: $\mathrm{MeOH} / \mathrm{H}_{2} \mathrm{O}$ (40:60); colorless oil; yield: $173 \mathrm{mg}$ ( $\left.0.81 \mathrm{mmol}, 81 \%\right)$. ${ }^{1} \mathrm{H} \mathrm{NMR}\left(400 \mathrm{MHz}, \mathrm{CDCl}_{3}\right) \delta 8.17(\mathrm{~d}, J=8.7 \mathrm{~Hz}, 2 \mathrm{H}), 7.36-7.32(\mathrm{~m}, 4 \mathrm{H})$, $7.28-7.26(\mathrm{~m}, 1 \mathrm{H}), 7.20(\mathrm{~s}, 2 \mathrm{H}), 4.10(\mathrm{~s}, 2 \mathrm{H})$.

These data are consistent with the previously reported characterization. ${ }^{23}$

\section{4-benzylbenzaldehyde (2j)}

Eluent: $\mathrm{MeOH} / \mathrm{H}_{2} \mathrm{O}$ (40:60); white solid; yield: $149 \mathrm{mg}$ ( $0.76 \mathrm{mmol}, 76 \%$ ). ${ }^{1} \mathrm{H} \mathrm{NMR}\left(400 \mathrm{MHz}, \mathrm{CDCl}_{3}\right) \delta 9.87(\mathrm{~s}, 1 \mathrm{H}), 7.70(\mathrm{~d}, J=8.1 \mathrm{~Hz}, 2 \mathrm{H}), 7.28-$ $7.18(\mathrm{~m}, 4 \mathrm{H}), 7.16-7.12(\mathrm{~m}, 1 \mathrm{H}), 7.11-7.05(\mathrm{~m}, 2 \mathrm{H}), 3.96(\mathrm{~s}, 2 \mathrm{H})$.

These data are consistent with the previously reported characterization. ${ }^{24}$

\section{(2-benzylphenyl)methanamine (2k)}

Eluent: $\mathrm{MeOH} / \mathrm{H}_{2} \mathrm{O}$ (40:60); white solid; yield: $172 \mathrm{mg}$ ( $\left.0.87 \mathrm{mmol}, 87 \%\right)$. 
${ }^{1} \mathrm{H} \mathrm{NMR}\left(400 \mathrm{MHz}, \mathrm{CDCl}_{3}\right) \delta 7.35(\mathrm{~d}, J=7.1 \mathrm{~Hz}, 1 \mathrm{H}), 7.28-7.16(\mathrm{~m}, 6 \mathrm{H})$, $7.13(\mathrm{t}, J=7.6 \mathrm{~Hz}, 2 \mathrm{H}), 4.06(\mathrm{~s}, 2 \mathrm{H}), 3.81(\mathrm{~s}, 2 \mathrm{H})$.

These data are consistent with the previously reported characterization. ${ }^{25}$

\section{2-benzyl-1,3-dimethylbenzene (2l)}

Eluent: $\mathrm{MeOH} / \mathrm{H}_{2} \mathrm{O}$ (70:30); colorless oil; yield: $190 \mathrm{mg}$ (0.97 mmol, 97\%). ${ }^{1} \mathrm{H} \mathrm{NMR}\left(400 \mathrm{MHz}, \mathrm{CDCl}_{3}\right) \delta 7.49-7.27(\mathrm{~m}, 5 \mathrm{H}), 7.26-7.23(\mathrm{~m}, 1 \mathrm{H}), 7.20$ (d, $J=7.2 \mathrm{~Hz}, 2 \mathrm{H}), 4.25(\mathrm{~s}, 2 \mathrm{H}), 2.43(\mathrm{~s}, 6 \mathrm{H})$.

These data are consistent with the previously reported characterization. ${ }^{26}$

\section{3-benzylthiophene (2m)}

Eluent: $\mathrm{MeOH} / \mathrm{H}_{2} \mathrm{O}$ (60:40); yellow oil; yield: $172 \mathrm{mg}(0.99 \mathrm{mmol}, 99 \%)$. $\left.{ }^{1} \mathrm{H} \mathrm{NMR} \mathrm{(400} \mathrm{MHz,} \mathrm{CDCl}_{3}\right) \delta 7.38-7.31(\mathrm{~m}, 2 \mathrm{H}), 7.31-7.23(\mathrm{~m}, 4 \mathrm{H}), 6.98$ $-6.94(\mathrm{~m}, 2 \mathrm{H}), 4.03(\mathrm{~s}, 2 \mathrm{H})$.

These data are consistent with the previously reported characterization. ${ }^{27}$

\section{3-benzylpyridine (2n)}

Eluent: $\mathrm{MeOH} / \mathrm{H}_{2} \mathrm{O}$ (40:60); yellow oil; yield: $167 \mathrm{mg}$ (0.99 mmol, 99\%). ${ }^{1} \mathrm{H}$ NMR $\left(400 \mathrm{MHz}, \mathrm{CDCl}_{3}\right) \delta 8.53-8.49(\mathrm{~m}, 1 \mathrm{H}), 8.48-8.44(\mathrm{~m}, 1 \mathrm{H}), 7.46$ $(\mathrm{dt}, J=7.7,1.8 \mathrm{~Hz}, 1 \mathrm{H}), 7.33-7.28(\mathrm{~m}, 2 \mathrm{H}), 7.25-7.16(\mathrm{~m}, 4 \mathrm{H}), 3.98(\mathrm{~s}$, $2 \mathrm{H})$.

These data are consistent with the previously reported characterization. ${ }^{28}$

\section{2-benzylbenzo[d]oxazole (2o)}

Eluent: $\mathrm{MeOH} / \mathrm{H}_{2} \mathrm{O}$ (50:50); yellow oil; yield: $205 \mathrm{mg}$ ( $\left.0.98 \mathrm{mmol}, 98 \%\right)$. ${ }^{1} \mathrm{H}$ NMR $\left(400 \mathrm{MHz}, \mathrm{CDCl}_{3}\right) \delta 7.64-7.59(\mathrm{~m}, 1 \mathrm{H}), 7.40-7.34(\mathrm{~m}, 1 \mathrm{H}), 7.33$ - $7.24(\mathrm{~m}, 4 \mathrm{H}), 7.23-7.16(\mathrm{~m}, 3 \mathrm{H}), 4.19$ (s, 2H).

These data are consistent with the previously reported characterization. ${ }^{29}$

\section{2-benzylbenzo[b]thiophene (2p)}

Eluent: $\mathrm{MeOH} / \mathrm{H}_{2} \mathrm{O}$ (50:50); white solid; yield: $222 \mathrm{mg}$ (0.99 mmol, 99\%). ${ }^{1} \mathrm{H} \mathrm{NMR}\left(400 \mathrm{MHz}, \mathrm{CDCl}_{3}\right) \delta 7.68(\mathrm{~d}, J=7.9 \mathrm{~Hz}, 1 \mathrm{H}), 7.60(\mathrm{~d}, J=7.5 \mathrm{~Hz}, 1 \mathrm{H})$, $7.30-7.16(\mathrm{~m}, 7 \mathrm{H}), 6.95(\mathrm{~s}, 1 \mathrm{H}), 4.17(\mathrm{~s}, 2 \mathrm{H})$.

These data are consistent with the previously reported characterization. ${ }^{30}$

\section{4-benzylisoquinoline (2q)}

Eluent: $\mathrm{MeOH} / \mathrm{H}_{2} \mathrm{O}$ (50:50); yellow solid; yield: $202 \mathrm{mg}$ (0.92 mmol, 92\%). ${ }^{1} \mathrm{H}$ NMR (400 MHz, $\mathrm{CDCl}_{3}$ ) $\delta 9.24(\mathrm{~s}, 1 \mathrm{H}), 8.47$ (s, $1 \mathrm{H}$ ), 7.99 (dd, $J=25.5,8.1$ $\mathrm{Hz}, 2 \mathrm{H}$ ), 7.69 (ddd, $J=8.4,6.9,1.3 \mathrm{~Hz}, 1 \mathrm{H}$ ), 7.62 (ddd, $J=7.9,6.7,1.0 \mathrm{~Hz}$ 1H), $7.34-7.29(\mathrm{~m}, 2 \mathrm{H}), 7.27-7.21(\mathrm{~m}, 3 \mathrm{H}), 4.43(\mathrm{~s}, 2 \mathrm{H})$

These data are consistent with the previously reported characterization. ${ }^{31}$

\section{3-phenethyl-1,1'-biphenyl (2r)}

Eluent: $\mathrm{MeOH} / \mathrm{H}_{2} \mathrm{O}$ (80:20); colorless oil; yield: $255 \mathrm{mg}$ (0.99 mmol, 99\%). ${ }^{1} \mathrm{H}$ NMR (400 MHz, $\left.\mathrm{CDCl}_{3}\right) \delta 7.60-7.56(\mathrm{~m}, 2 \mathrm{H}), 7.48-7.42(\mathrm{~m}, 3 \mathrm{H}), 7.41$ - $7.29(\mathrm{~m}, 5 \mathrm{H}), 7.25-7.17(\mathrm{~m}, 4 \mathrm{H}), 2.99(\mathrm{t}, J=2.5 \mathrm{~Hz}, 4 \mathrm{H})$.

${ }^{13} \mathrm{C}$ NMR $\left(101 \mathrm{MHz}, \mathrm{CDCl}_{3}\right) \delta 142.37,141.86,141.50,141.43,128.89$, 128.84, 128.64, 128.51, 127.57, 127.54, 127.33, 126.10, 124.98, 38.19, 38.15 .

GC-MS: $\mathrm{m} / \mathrm{z}=258.139$.

\section{3-phenylpyridine (3a)}

Eluent: $\mathrm{MeOH} / \mathrm{H}_{2} \mathrm{O}$ (40:60); yellow oil; yield: $153 \mathrm{mg}$ (0.99 mmol, 99\%).
${ }^{1} \mathrm{H}$ NMR $\left(500 \mathrm{MHz}, \mathrm{CDCl}_{3}\right) \delta 8.85(\mathrm{~s}, 1 \mathrm{H}), 8.59(\mathrm{~d}, J=3.9 \mathrm{~Hz}, 1 \mathrm{H}), 7.86(\mathrm{dt}$ $J=7.9,2.0 \mathrm{~Hz}, 1 \mathrm{H}), 7.60-7.55(\mathrm{~m}, 2 \mathrm{H}), 7.49-7.45(\mathrm{~m}, 2 \mathrm{H}), 7.43-7.37(\mathrm{~m}$, $1 \mathrm{H}), 7.35$ (dd, $J=7.9,4.7 \mathrm{~Hz}, 1 \mathrm{H})$.

These data are consistent with the previously reported characterization. ${ }^{32}$

\section{3,3'-bipyridine (3b)}

Eluent: $\mathrm{MeOH} / \mathrm{H}_{2} \mathrm{O}$ (30:70); white solid; yield: $147 \mathrm{mg}$ (0.94 mmol, 94\%). ${ }^{1} \mathrm{H}$ NMR (500 MHz, $\left.\mathrm{CDCl}_{3}\right) \delta 8.86(\mathrm{~d}, J=1.9 \mathrm{~Hz}, 2 \mathrm{H}), 8.67(\mathrm{dd}, J=4.8,1.6$ $\mathrm{Hz}, 2 \mathrm{H}$ ), $7.92-7.87$ (m, 2H), 7.42 (ddd, $J=7.9,4.8,0.8 \mathrm{~Hz}, 2 \mathrm{H}$ ).

These data are consistent with the previously reported characterization. ${ }^{33}$

\section{3-benzhydrylpyridine (3c)}

Eluent: $\mathrm{MeOH} / \mathrm{H}_{2} \mathrm{O}$ (60:40); colorless oil; yield: $223 \mathrm{mg}$ (0.91 mmol, 91\%). ${ }^{1} \mathrm{H}$ NMR $\left(500 \mathrm{MHz}, \mathrm{CDCl}_{3}\right) \delta 8.48(\mathrm{dd}, J=4.8,1.7 \mathrm{~Hz}, 1 \mathrm{H}), 8.44(\mathrm{~d}, J=2.3$ $\mathrm{Hz}, 1 \mathrm{H}), 7.40(\mathrm{dt}, J=7.9,2.0 \mathrm{~Hz}, 1 \mathrm{H}), 7.33-7.28(\mathrm{~m}, 4 \mathrm{H}), 7.26-7.20(\mathrm{~m}$, $3 \mathrm{H}), 7.13-7.09(\mathrm{~m}, 4 \mathrm{H}), 5.56(\mathrm{~s}, 1 \mathrm{H})$.

These data are consistent with the previously reported characterization. ${ }^{34}$

\section{4-(pyridin-3-yl)butanenitrile (3d)}

Eluent: $\mathrm{MeOH} / \mathrm{H}_{2} \mathrm{O}$ (40:60); brown oil; yield: $133 \mathrm{mg}$ (0.91 mmol, 91\%). ${ }^{1} \mathrm{H} \mathrm{NMR}\left(500 \mathrm{MHz}, \mathrm{CDCl}_{3}\right) \delta 8.58-8.51(\mathrm{~m}, 2 \mathrm{H}), 7.64(\mathrm{dt}, J=8.0,2.0 \mathrm{~Hz}$, $1 \mathrm{H}), 7.35(\mathrm{dd}, J=7.8,5.0 \mathrm{~Hz}, 1 \mathrm{H}), 2.81(\mathrm{t}, J=7.5 \mathrm{~Hz}, 2 \mathrm{H}), 2.38(\mathrm{t}, J=7.0 \mathrm{~Hz}$, $2 \mathrm{H}), 2.02-1.95(\mathrm{~m}, 2 \mathrm{H})$.

These data are consistent with the previously reported characterization. ${ }^{35}$

\section{3-(3-((tert-butyldimethylsilyl)oxy)propyl)pyridine (3e)}

Eluent: $\mathrm{MeOH} / \mathrm{H}_{2} \mathrm{O}$ (60:40); yellow oil; yield: $229 \mathrm{mg}$ (0.91 mmol, 91\%). ${ }^{1} \mathrm{H} \mathrm{NMR}\left(500 \mathrm{MHz}, \mathrm{CDCl}_{3}\right) \delta 8.43(\mathrm{~d}, J=1.9 \mathrm{~Hz}, 1 \mathrm{H}), 8.40(\mathrm{dd}, J=4.8,1.6$ $\mathrm{Hz}, 1 \mathrm{H}), 7.50$ (dt, $J=7.8,1.8 \mathrm{~Hz}, 1 \mathrm{H}), 7.19(\mathrm{dd}, J=7.8,4.8 \mathrm{~Hz}, 1 \mathrm{H}), 3.61(\mathrm{t}, J$ $=6.1 \mathrm{~Hz}, 2 \mathrm{H}), 2.70-2.65(\mathrm{~m}, 2 \mathrm{H}), 1.85-1.77(\mathrm{~m}, 2 \mathrm{H}), 0.90(\mathrm{~s}, 6 \mathrm{H}), 0.89(\mathrm{~s}$, $9 \mathrm{H})$.

These data are consistent with the previously reported characterization. ${ }^{36}$

\section{2-(2-(pyridin-3-yl)ethyl)isoindoline-1,3-dione (3f)}

Eluent: $\mathrm{MeOH} / \mathrm{H}_{2} \mathrm{O}$ (50:50); white solid; yield: $209 \mathrm{mg}$ (0.83 mmol, 83\%). ${ }^{1} \mathrm{H}$ NMR $\left(500 \mathrm{MHz}, \mathrm{CDCl}_{3}\right) \delta 8.47-8.38(\mathrm{~m}, 2 \mathrm{H}), 7.82(\mathrm{dd}, J=5.5,3.0 \mathrm{~Hz}$, $2 \mathrm{H}), 7.70(\mathrm{dd}, J=5.4,3.0 \mathrm{~Hz}, 2 \mathrm{H}), 7.52(\mathrm{dt}, J=7.8,2.0 \mathrm{~Hz}, 1 \mathrm{H}), 7.17(\mathrm{dd}, J=$ $7.8,4.8 \mathrm{~Hz}, 1 \mathrm{H}), 3.74(\mathrm{t}, J=7.1 \mathrm{~Hz}, 2 \mathrm{H}), 2.73-2.63(\mathrm{~m}, 2 \mathrm{H}), 2.06-1.99(\mathrm{~m}$, $2 \mathrm{H})$.

These data are consistent with the previously reported characterization. ${ }^{37}$

\section{diethyl (2-(pyridin-3-yl)ethyl)phosphonate (3g)}

Eluent: $\mathrm{MeOH} / \mathrm{H}_{2} \mathrm{O}$ (40:60); yellow oil; yield: $180 \mathrm{mg}$ (0.74 mmol, 74\%). ${ }^{1} \mathrm{H}$ NMR $\left(500 \mathrm{MHz}, \mathrm{CDCl}_{3}\right) \delta 8.50-8.44(\mathrm{~m}, 2 \mathrm{H}), 7.55-7.50(\mathrm{~m}, 1 \mathrm{H}), 7.22$ $(\mathrm{dd}, J=7.8,4.8 \mathrm{~Hz}, 1 \mathrm{H}), 4.12-4.05(\mathrm{~m}, 4 \mathrm{H}), 2.96-2.87(\mathrm{~m}, 2 \mathrm{H}), 2.08-$ $2.00(\mathrm{~m}, 2 \mathrm{H}), 1.30(\mathrm{t}, J=7.1 \mathrm{~Hz}, 6 \mathrm{H})$.

These data are consistent with the previously reported characterization. ${ }^{38}$

\section{(4-(pyridin-3-ylmethyl)phenyl)boronic acid (3h)}

Eluent: $\mathrm{MeOH} / \mathrm{H}_{2} \mathrm{O}$ (40:60); white solid; yield: $151 \mathrm{mg}$ (0.71 mmol, 71\%).

${ }^{1} \mathrm{H}$ NMR (400 MHz, $\left.\mathrm{CDCl}_{3}\right) \delta 8.71-8.58(\mathrm{~m}, 2 \mathrm{H}), 7.99(\mathrm{~d}, J=7.6 \mathrm{~Hz}, 2 \mathrm{H})$, $7.65(\mathrm{dt}, J=7.9,1.9 \mathrm{~Hz}, 1 \mathrm{H}), 7.39-7.31(\mathrm{~m}, 1 \mathrm{H}), 7.25(\mathrm{~d}, J=7.7 \mathrm{~Hz}, 2 \mathrm{H})$, $4.07(\mathrm{~s}, 2 \mathrm{H})$

${ }^{13} \mathrm{C}$ NMR $\left(101 \mathrm{MHz}, \mathrm{CDCl}_{3}\right) \delta 148.29,145.41,140.38,138.02,137.87$, $134.23,129.89,128.15,124.11,116.07,39.31$. 
LC-MS: $\mathrm{m} / \mathrm{z}=214.051$.

mp: $148^{\circ} \mathrm{C}$

\section{ethyl 2-(pyridin-3-yl)acetate (3i)}

Eluent: $\mathrm{MeOH} / \mathrm{H}_{2} \mathrm{O}$ (40:60); yellow oil; yield: $104 \mathrm{mg}$ (0.63 mmol, 63\%).

${ }^{1} \mathrm{H}$ NMR (500 MHz, $\left.\mathrm{CDCl}_{3}\right) \delta 8.52-8.47(\mathrm{~m}, 2 \mathrm{H}), 7.61(\mathrm{dt}, J=7.8,2.1 \mathrm{~Hz}$ 1H), 7.23 (dd, $J=8.1,4.9 \mathrm{~Hz}, 1 \mathrm{H}), 4.14(\mathrm{q}, J=7.1 \mathrm{~Hz}, 2 \mathrm{H}), 3.59$ (s, 2H), 1.23 $(\mathrm{t}, J=7.1 \mathrm{~Hz}, 3 \mathrm{H})$.

These data are consistent with the previously reported characterization. ${ }^{39}$

\section{3-(prop-1-en-2-yl)pyridine (3j)}

Eluent: $\mathrm{MeOH} / \mathrm{H}_{2} \mathrm{O}$ (50:50); yellow solid; yield: $118 \mathrm{mg}$ (0.99 mmol, 99\%). ${ }^{1} \mathrm{H}$ NMR (500 MHz, $\mathrm{CDCl}_{3}$ ) $\delta 8.72(\mathrm{~d}, J=2.4 \mathrm{~Hz}, 1 \mathrm{H}), 8.50(\mathrm{dd}, J=4.9,1.7$ $\mathrm{Hz}, 1 \mathrm{H}), 7.73(\mathrm{dt}, J=8.1,2.0 \mathrm{~Hz}, 1 \mathrm{H}), 7.28-7.22(\mathrm{~m}, 1 \mathrm{H}), 5.42(\mathrm{~s}, 1 \mathrm{H}), 5.18$ $(\mathrm{s}, 1 \mathrm{H}), 2.16(\mathrm{~s}, 3 \mathrm{H})$

These data are consistent with the previously reported characterization. ${ }^{40}$

\section{3-ethynylpyridine (3k)}

Eluent: $\mathrm{MeOH} / \mathrm{H}_{2} \mathrm{O}$ (50:50); white solid; yield: $59 \mathrm{mg}$ (0.57 mmol, 57\%). ${ }^{1} \mathrm{H}$ NMR $\left(400 \mathrm{MHz}, \mathrm{CDCl}_{3}\right) \delta 8.72(\mathrm{~s}, 1 \mathrm{H}), 8.57(\mathrm{~d}, J=4.8 \mathrm{~Hz}, 1 \mathrm{H}), 7.77$ (dd, $J=7.9,1.8 \mathrm{~Hz}, 1 \mathrm{H}), 7.29-7.23(\mathrm{~m}, 1 \mathrm{H}), 3.22(\mathrm{~s}, 1 \mathrm{H})$.

These data are consistent with the previously reported characterization. ${ }^{41}$

\section{Funding Information}

SQ Tang's PhD scholarship was funded by the Ministry of Education of the P.R. China (China Scholarship Council (201608310124))

\section{Acknowledgment}

Click here to insert acknowledgment text. Funding sources and grant numbers should be given above in the Funding Information section.

\section{Supporting Information}

YES (this text will be updated with links prior to publication)

\section{Primary Data}

NO (this text will be deleted prior to publication)

\section{References}

(1) (a) Barl, N. M.; Malakhov, V.; Mathes, C.; Lustenberger, P.; Knochel, P. Synthesis 2015, 47, 692. (b) Milne, J. E.; Buchwald, S. L. J. Am. Chem. Soc. 2004, 126, 13028. (c) Lee, H.; Lee, Y.; Cho, S. H. Org. Lett. 2019, 21, 5912. (d) Xia, T.; He, L.; Liu, Y. A.; Hartwig, J. F.; Liao, X. Org. Lett. 2017, 19, 2610. (e) Duez, S.; Bernhardt, S.; Heppekausen, J.; Fleming, F. F.; Knochel, P. Org. Lett. 2011, 13, 1690. (f) Melzig, L.; Stemper, J.; Knochel, P. Synthesis 2010, 2085.

(2) Hazari, N.; Melvin, P. R.; Beromi, M. M. Nat. Rev. Chem. 2017, 0025 .

(3) Tang, S. Q.; Bricard, J.; Schmitt, M.; Bihel, F. Org. Lett. 2019, 21 , 844.

(4) (a) Schoenberg, A.; Heck, R. F. J. Org. Chem. 1974, 39, 3327. (b) Sekiya, A.; Ishikawa, N. J. Organomet. Chem. 1976, 118, 349.

(5) Fauvarque, J. F.; Jutand, A. J. Organomet. Chem. 1979, 177, 273.
(6) Flemming, J. P.; Pilon, M. C.; Borbulevitch, O. Y.; Antipin, M. Y.; Grushin, V. V. Inorg. Chim. Acta 1998, 280, 87.

(7) Bruno, N. C.; Tudge, M. T.; Buchwald, S. L. Chem. Sci. 2013, 4, 916.

(8) Valente, C.; Belowich, M. E.; Hadei, N.; Organ, M. G. Eur. J. Org. Chem. 2010, 4343.

(9) Dong, Z.-B.; Manolikakes, G.; Shi, L.; Knochel, P.; Mayr, H. Chem. Eur. J. 2010, 16, 248.

(10) Negishi, E.; Xu, C. D.; Tan, Z.; Kotora, M. Heterocycles 1997, 46, 209

(11) Yamanaka, H.; Annaka, M.; Kondo, Y.; Sakamoto, T. Chem. Pharm. Bull. 1985, 33, 4309.

(12) Ingoglia, B. T.; Buchwald, S. L. Org. Lett. 2017, 19, 2853.

(13) Metzger, A.; Schade, M. A.; Knochel, P. Org. Lett. 2008, 10, 1107.

(14) Krasovskiy, A.; Knochel, P. Synthesis 2006, 0890.

(15) Schade, M. A.; Manolikakes, G.; Knochel, P. Org. Lett. 2010, 12, 3648.

(16) Tsang, M. Y.; Viñas, C.; Teixidor, F.; Planas, J. G.; Conde, N.; SanMartin, R.; Herrero, M. T.; Domínguez, E.; Lledós, A.; Vidossich, P.; Choquesillo-Lazarte, D. Inorg. Chem. 2014, 53, 9284.

(17) Li, X.; Feng, Y.; Lin, L.; Zou, G. J. Org. Chem. 2012, 77, 10991.

(18) Zhang, L.; Ang, G. Y.; Chiba, S. Org. Lett. 2011, 13, 1622.

(19) Runyon, S. P.; Peddi, S.; Savage, J. E.; Roth, B. L.; Glennon, R. A.; Westkaemper, R. B. J. Med. Chem. 2002, 45, 1656.

(20) Maity, P.; Shacklady-McAtee, D. M.; Yap, G. P. A.; Sirianni, E. R.; Watson, M. P. J. Am. Chem. Soc. 2013, 135, 280.

(21) Cheng, Y.; Dong, W.; Wang, L.; Parthasarathy, K.; Bolm, C. Org. Lett. 2014, 16, 2000.

(22) Baguley, T. D.; Xu, H.-C.; Chatterjee, M.; Nairn, A. C.; Lombroso, P. J.; Ellman, J. A. J. Med. Chem. 2013, 56, 7636.

(23) McLaughlin, M. Org. Lett. 2005, 7, 4875.

(24) Yoon, S.; Hong, M. C.; Rhee, H. J. Org. Chem. 2014, 79, 4206.

(25) Kick, E. K.; Smallheer, J. M.; Shaw, S. A.; Vokits, B. P.; Dilger, A. K.; Clark, C. G.; Valente, M. N.; Jusuf, S.; Wurtz, N. R. PCT Int. Appl. WO 2017161145, 2017.

(26) García Martínez, A.; Osío Barcina, J.; Colorado Heras, M. d. R.; de Fresno Cerezo, Á. Organometallics 2001, 20, 1020.

(27) Kuriyama, M.; Shinozawa, M.; Hamaguchi, N.; Matsuo, S.; Onomura, O. J. Org. Chem. 2014, 79, 5921.

(28) Molander, G. A.; Elia, M. D. J. Org. Chem. 2006, 71, 9198.

(29) Evindar, G.; Batey, R. A. J. Org. Chem. 2006, 71, 1802.

(30) Lapointe, D.; Fagnou, K. Org. Lett. 2009, 11, 4160

(31) Huang, J.-R.; Bolm, C. Angew. Chem., Int. Ed. 2017, 56, 15921.

(32) Kuriyama, M.; Matsuo, S.; Shinozawa, M.; Onomura, O. Org. Lett 2013, 15, 2716.

(33) Billingsley, K.; Buchwald, S. L. J. Am. Chem. Soc. 2007, 129, 3358 (34) Xia, Y.; Hu, F.; Liu, Z.; Qu, P.; Ge, R.; Ma, C.; Zhang, Y.; Wang, J. Org. Lett. 2013, 15, 1784.

(35) Menghin, S.; Pertz, H. H.; Kramer, K.; Seifert, R.; Schunack, W.; Elz, S. J. Med. Chem. 2003, 46, 5458.

(36) Maia, Alessandra A.; Mons, S.; Pereira de Freitas Gil, R.; Marazano, C. Eur. J. Org. Chem. 2004, 1057.

(37) Geyer, R.; Igel, P.; Kaske, M.; Elz, S.; Buschauer, A. MedChemComm 2014, 5, 72 .

(38) Phan, H. T.; Nguyen, L. M.; Azoulay, R.; Diep, V. V.; Niesor, E. J.; Bentzen, C. L.; Ife, R. J. PCT Int. Appl. WO 2003068240, 2003.

(39) Zhu, Y.-G.; Kan, H.-Z.; Jiang, L.-Q.; Hu, W.-H. Synth. Commun. 2012, 42, 1137.

(40) Gärtner, D.; Stein, A. L.; Grupe, S.; Arp, J.; Jacobi von Wangelin, A. Angew. Chem., Int. Ed. 2015, 54, 10545.

(41) Feng, Y.-S.; Xie, C.-Q.; Qiao, W.-L.; Xu, H.-J. Org. Lett. 2013, 15, 936. 